\title{
COMPARISON OF INDEPENDENT $\Delta^{14} \mathrm{CO}_{2}$ RECORDS AT POINT BARROW, ALASKA
}

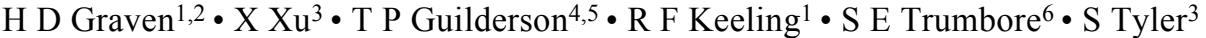

\begin{abstract}
Two independent programs have collected and analyzed atmospheric $\mathrm{CO}_{2}$ samples from Point Barrow, Alaska, for radiocarbon content $\left(\Delta^{14} \mathrm{C}\right)$ over the period 2003-2007. In one program, flask collection, stable isotope analysis, and $\mathrm{CO}_{2}$ extraction are performed by the Scripps Institution of Oceanography's $\mathrm{CO}_{2}$ Program and $\mathrm{CO}_{2}$ is graphitized and measured by accelerator mass spectrometry (AMS) at Lawrence Livermore National Laboratory. In the other program, the University of California, Irvine, performs flask collection, sample preparation, and AMS. Over 22 common sample dates spanning $5 \mathrm{yr}$, differences in measured $\Delta{ }^{14} \mathrm{C}$ are consistent with the reported uncertainties and there is no significant bias between the programs.
\end{abstract}

\section{INTRODUCTION}

A standard method to assess the comparability of radiocarbon laboratories is to distribute common materials for independent processing and analysis at each laboratory (Polach 1989; Scott 2003), including $\mathrm{CO}_{2}$ in dry air (Miller et al. 2011, 2013). For laboratories analyzing ${ }^{14} \mathrm{C}$ content $\left({ }^{14} \mathrm{C}\right)$ in atmospheric $\mathrm{CO}_{2}$, a more complete intercomparison is possible using duplicate atmospheric samples collected at the same location and time. This allows for comparing all factors influencing the measurements, including sampling, storage, processing, and analysis. Such co-located sampling programs have been utilized for assessing comparability of laboratories measuring the concentration of atmospheric $\mathrm{CO}_{2}$ and other atmospheric compounds (Hudec and Trivett 1997; Masarie et al. 2001), but they have not yet been employed for $\Delta^{14} \mathrm{C}$ in $\mathrm{CO}_{2}$ measured by accelerator mass spectrometry (AMS).

Here, we compare 2 independent measurement programs for $\Delta^{14} \mathrm{C}$ in $\mathrm{CO}_{2}$ at Point Barrow, Alaska. One program is run by a collaboration between the Scripps Institution of Oceanography and Lawrence Livermore National Laboratory (SIO/LLNL) and the other program is run by the University of California, Irvine (UCI). The programs employ whole air flask sampling, $\mathrm{CO}_{2}$ extraction and graphitization, and AMS using slightly different techniques described below.

Our analysis focuses on a statistical comparison of $\Delta^{14} \mathrm{C}$ measurements on groups of samples that were collected on the same date by both programs. We determine whether the differences in $\Delta^{14} \mathrm{C}$ are commensurate with the reported measurement uncertainties and evaluate the data for any consistent bias in $\Delta^{14} \mathrm{C}$ between the 2 programs.

\footnotetext{
${ }^{1}$ Scripps Institution of Oceanography, University of California, San Diego, 9500 Gilman Dr., La Jolla, California $92093-$ 0244, USA.

${ }^{2}$ Corresponding author. Email: hgraven@ucsd.edu.

${ }^{3}$ Department of Earth System Science, University of California, Irvine, Irvine, California 92697-3100, USA.

${ }^{4}$ Center for Accelerator Mass Spectrometry, Lawrence Livermore National Laboratory L-397, 7000 East Ave., Livermore, California 94550, USA.

${ }^{5}$ Department of Ocean Sciences, University of California, Santa Cruz, Santa Cruz, California 95064, USA.

${ }^{6}$ Max Planck Institute of Biogeochemistry, Postfach 1001 64, 07701 Jena, Germany.
}

C 2013 by the Arizona Board of Regents on behalf of the University of Arizona

Proceedings of the 21st International Radiocarbon Conference edited by A J T Jull \& C Hatté

RADIOCARBON, Vol 55, Nr 2-3, 2013, p 1541-1545 


\section{H D Graven et al.}

\section{METHODS}

\section{SIO/LLNL Measurements}

The Scripps $\mathrm{CO}_{2}$ Program collects whole air samples at Point Barrow using 5-L glass flasks that have been pre-evacuated at SIO (Keeling et al. 2001). Flasks are filled to atmospheric pressure by opening a single glass stopcock sealed with Apiezon ${ }^{\circledR}$ grease. $\mathrm{CO}_{2}$ concentration is measured in the flask at $\mathrm{SIO}$ and then $\mathrm{CO}_{2}$ is extracted cryogenically from a portion of the remaining air and sealed in Pyrex ${ }^{\circledR}$ tubes. Each sample is approximately $0.5 \mathrm{mg} \mathrm{C}$ in size.

At LLNL, $\mathrm{CO}_{2}$ samples are converted to graphite by reducing with $\mathrm{H}_{2}$ gas over an iron catalyst and then measured by AMS (Graven et al. 2007; Graven 2008). Measurements are reported as $\Delta^{14} \mathrm{C}$ (equivalent to $\Delta$ in the work by Stuiver and Polach [1977]), where $\delta^{13} \mathrm{C}$ measurements from concurrent samples (Keeling et al. 2001) are used to correct for mass dependent fractionation. Total measurement uncertainty for $\Delta^{14} \mathrm{C}$ in $\mathrm{CO}_{2}$ is $\pm 1.7-2.8 \%$ (Graven et al. 2007, 2012; Graven 2008).

\section{UCI Measurements}

The UCI program collects whole air samples at Point Barrow using 6-L, 1-valve stainless steel canisters (Silco Can, Restek Co.) that have been pre-evacuated at UCI (Xu et al. 2007a). The canisters are pressurized to $\sim 2 \mathrm{~atm}$ using an oil-free pump (Tyler et al. 2007). For the period from 17 June 2005 to 17 March 2006, 6 air samples that are included in this study were collected using 32-L, 1-valve stainless steel canisters (Tyler et al. 2007). Subsamples were then taken from these samples for ${ }^{14} \mathrm{C}$ analysis. $\mathrm{CO}_{2}$ is extracted cryogenically at $\mathrm{UCI}$ then converted to graphite by the sealed tube zinc reduction method (Xu et al. 2007b). Each sample is $\sim 2.7 \mathrm{mg} \mathrm{C}$ in size. Analysis of $\Delta{ }^{14} \mathrm{C}$ is performed at the W M Keck AMS facility at UCI with total measurement uncertainty of $\pm 1.3-2.4 \%$ ( $\mathrm{X} \mathrm{Xu}$, unpublished data). Mass dependent fractionation is corrected for using "on-line" $\delta^{13} \mathrm{C}$ measurements during AMS analysis, which accounts for fractionation that occurred during graphitization and inside the AMS.

\section{Comparison of the Two Programs}

The observations from SIO/LLNL and UCI overlap for the period 2003-2007, with 22 individual sample dates common to both programs (Figure 1). For 13 of the 22 sample dates, replicate samples were collected and analyzed for $\Delta^{14} \mathrm{C}$ by the UCI program. No replicate observations were made by the SIO/LLNL program.

We compare the observations by first averaging any replicate measurements from UCI, then averaging the mean $\Delta^{14} \mathrm{C}$ from UCI with the $\Delta^{14} \mathrm{C}$ measured by SIO/LLNL. We calculate the residual by subtracting this overall mean from the $\Delta^{14} \mathrm{C}$ measured by each program. The bias is given by the difference in the average residual for UCI and SIO/LLNL ( $\mu_{\mathrm{UCI}}$ and $\left.\mu_{\mathrm{SIO} / \mathrm{LLN}}\right)$, which is compared to the standard error to assess significance.

Flasks from both programs are filled by NOAA personnel at the Point Barrow station, who check for clean air conditions prior to filling flasks for trace gas and isotope analyses. Most of the SIO and UCI flasks were collected within an hour of each other on each sample date, with sampling times between 8:00 and 15:30 local time. However, for 8 sample dates, indicated by empty symbols in Figure 1, the SIO flask was collected 4-6 hr later than the UCI flask(s). We also perform separate calculations of the bias for samples collected with larger time differences, in case the measurements are affected by natural daily variations. 


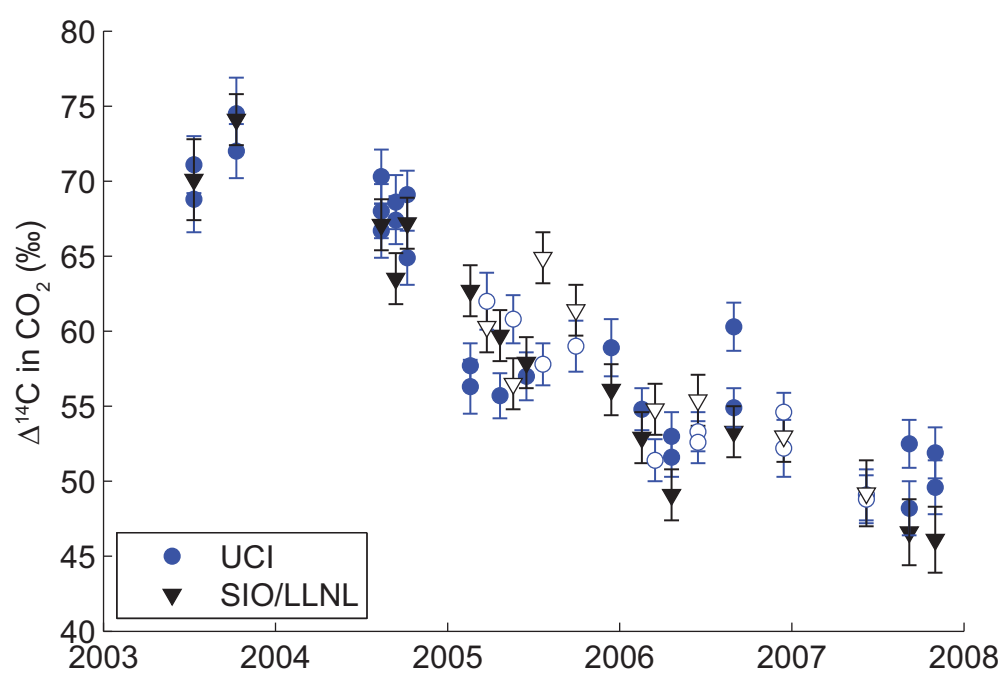

Figure 1 Observations of $\Delta^{14} \mathrm{CO}_{2}$ at Point Barrow, Alaska, for sample dates in common from the SIO/LLNL and UCI measurement programs. Filled symbols indicate the UCI and SIO flasks were collected within $1 \mathrm{hr}$ of each other, while empty symbols indicate the SIO flask was collected 4-6 hr later than the UCI flask on that date.

\section{RESULTS}

There is very good agreement between the $\Delta^{14} \mathrm{CO}_{2}$ measurements from the SIO/LLNL and UCI programs at Point Barrow. The residual $\Delta{ }^{14} \mathrm{C}$ is within $\pm 1 \sigma$ for $60 \%$ of the sample dates, and within $\pm 2 \sigma$ for all but 1 sample date (Figure 2). For 5 of the 13 sample dates with replicate samples from UCI, the SIO/LLNL measurement was bracketed by the UCI measurements (Figure 1). Correspondence between the 2 laboratories is consistent with their average reported uncertainties of $\pm 1.7 \%$.

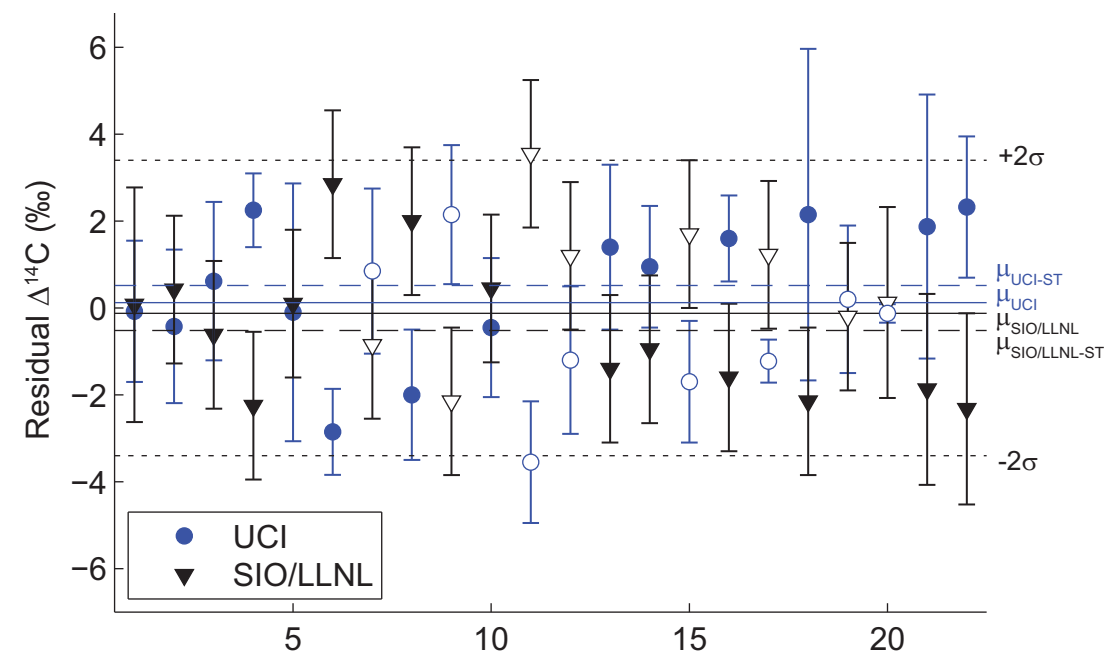

Figure 2 Residual $\Delta^{14} \mathrm{C}$ for 22 individual sample dates. Replicate samples from UCI have been averaged. Error bars show the reported measurement uncertainty or, for UCI, the standard deviation in replicate measurements. The average residuals, $\mu_{\mathrm{UCI}}$ and $\mu_{\mathrm{SIO} / \mathrm{LLNL}}$, are shown by solid lines. The average residuals for samples collected within $1 \mathrm{hr}$ of each other only, $\mu_{\mathrm{UCI}-\mathrm{ST}}$ and $\mu_{\mathrm{SIO} / \mathrm{LLNL}-\mathrm{ST}}$, are shown by dashed lines. Dotted lines show a $\pm 2 \sigma$ envelope around the average reported uncertainty of $\pm 1.7 \%$. 


\section{H D Graven et al.}

There is no significant bias between the 2 programs. The difference in the average residuals is $0.2 \pm$ $0.7 \%$ for UCI compared to SIO/LLNL (Figure 2, Table 1). Including only the samples collected with $1 \mathrm{hr}$ of each other increases the mean bias to $1.0 \%$, but it remains similar to the standard error of $\pm 0.9 \%$. Likewise, the mean bias in the samples collected more than $4 \mathrm{hr}$ apart is not significantly different from zero $(-1.2 \pm 1.3 \%$, Table 1$)$.

Diurnal variations of $\Delta^{14} \mathrm{C}$ have not been characterized at Point Barrow, but observations of $\mathrm{CO}_{2}$ concentration vary by only $\pm 0.4 \mathrm{ppm}$ between the morning and afternoon (Thoning et al. 2012). Making the extreme assumption that this variation was due to ${ }^{14} \mathrm{C}$-free $\mathrm{CO}_{2}$, this would cause $\Delta^{14} \mathrm{C}$ to vary by only $\pm 1 \%$, which we can take as an upper bound to the corresponding $\Delta^{14} \mathrm{C}$ variability. Our observations also indicate that diurnal cycles in $\Delta^{14} \mathrm{C}$ at Point Barrow are small, and that samples collected at different times of day are likely to have consistent $\Delta{ }^{14} \mathrm{C}$ values. A lack of diurnal variation reflects the remoteness of Point Barrow, differing from sampling stations located near local fossil fuel emission sources where $\Delta^{14} \mathrm{C}$ is typically higher in the afternoon because of enhanced ventilation of emissions (Graven et al. 2009; Newman et al. 2012).

Table 1 Bias (UCI-SIO/LLNL) and standard error in all samples, in samples collected within $1 \mathrm{hr}$ of each other and in samples collected more than $4 \mathrm{hr}$ apart.

\begin{tabular}{lc}
\hline Group & Bias and standard error \\
\hline All samples & $0.2 \pm 0.7 \%$ \\
Collected within $1 \mathrm{hr}$ & $1.0 \pm 0.9 \%$ \\
Collected more than $4 \mathrm{hr}$ apart & $-1.2 \pm 1.3 \% \mathrm{o}$ \\
\hline
\end{tabular}

\section{CONCLUSIONS}

Our comparison shows there is no significant bias between measurements of $\Delta^{14} \mathrm{C}$ in atmospheric $\mathrm{CO}_{2}$ conducted by SIO/LLNL and UCI at Point Barrow. The 2 programs meet the $\pm 1 \%$ criteria for comparability recommended by the World Meteorological Organization (WMO 2011). As SIO/ LLNL and UCI both perform $\Delta^{14} \mathrm{C}$ measurements at several other sites, this result suggests that observations from the 2 programs at other sites can be compiled and compared without adjustment of the reported data.

\section{ACKNOWLEDGMENTS}

We are grateful to NOAA and the Point Barrow field station personnel for collecting flask samples. Alane Bollenbacher performed stable isotopic analyses at SIO. A portion of this work was performed under the auspices of the US Department of Energy under contract DE-AC52-07NA27344.

\section{REFERENCES}

Graven HD. 2008. Advancing the use of radiocarbon in studies of global and regional carbon cycling with high precision measurements of ${ }^{14} \mathrm{C}$ in $\mathrm{CO}_{2}$ from the Scripps $\mathrm{CO}_{2}$ Program [PhD thesis]. La Jolla: Scripps Institute of Oceanography, University of California, San Diego.

Graven HD, Guilderson TP, Keeling RF. 2007. Methods for high-precision ${ }^{14} \mathrm{C}$ AMS measurement of atmospheric $\mathrm{CO}_{2}$ at LLNL. Radiocarbon 49(2):349-56.

Graven HD, Stephens BB, Guilderson TP, Keeling RF, Campos TL, Campbell JE, Schimel DS. 2009. Estimates of biospheric and fossil fuel-derived $\mathrm{CO}_{2}$ and fossil fuel $\mathrm{CO}_{2}$ :CO ratios from airborne measurements of $\Delta{ }^{14} \mathrm{C}, \mathrm{CO}_{2}$, and $\mathrm{CO}$ above Colorado. Tellus $B$ 61(3):536-46.

Graven HD, Guilderson TP, Keeling RF. 2012. Observations of radiocarbon in $\mathrm{CO}_{2}$ at seven global sampling sites in the Scripps flask network: analysis of spatial gradients and seasonal cycles. Journal of Geophysical Research 117: D02303, doi:10.1029/2011JD016535.

Hudec VC, Trivett NBA. 1997. An evaluation of $\mathrm{CO}_{2}$ flask measurement programs at Alert, N.W.T. In: Report of the Eighth WMO Meeting of Experts on Carbon Dioxide Concentration and Isotopic Measure- 


\section{Comparison of $\triangle^{14} \mathrm{CO}_{2}$ Records at Point Barrow}

ment Techniques, Boulder, USA, 6-11 July 1995. WMO TD No. 821. Geneva: World Meteorological Organization Atmospheric Watch. p 42-57.

Keeling CD, Piper SC, Bacastow RB, Wahlen M, Whorf TP, Heimann M, Meijer HA. 2001. Exchanges of atmospheric $\mathrm{CO}_{2}$ and ${ }^{13} \mathrm{CO}_{2}$ with the terrestrial biosphere and oceans from 1978 to 2000. I. Global aspects, SIO Reference Series, No. 01-06, Scripps Institution of Oceanography, San Diego. 88 p.

Masarie KA, Langenfelds RL, Allison CE, Conway TJ, Dlugokencky EJ, Francey RJ, Novelli PC, Steele LP, Tans PP, Vaughn B, White JWC. 2001. NOAA/CSIRO Flask Air Intercomparison Experiment: a strategy for directly assessing consistency among atmospheric measurements made by independent laboratories. Journal of Geophysical Research 106(D17):20,44564.

Miller J, Wolak C, Lehman S, Allison C, Graven H, Guilderson T, Keeling R, Meijer H, Nakamura T, Nakazawa T, Neubert R, Smith A, Southon J, Xu X. 2011. Preliminary results from the first inter-comparison of accelerator mass spectrometry atmospheric ${ }^{14} \mathrm{CO}_{2}$ measurements. In: Brand W, editor. Report of the 15th WMO/IAEA Meeting of Experts on Carbon Dioxide, Other Greenhouse Gases and Related Tracers Measurement Techniques, 2009. Report 194. Geneva: World Meteorological Organization Atmospheric Watch. p 216-8.

Miller J, Lehman S, Wolak C, Turnbull J, Dunn G, Graven H, Keeling R, Meijer HAJ, AT Aerts-Bijma, Palstra SWL, Smith AM, Allison C, Southon J, Xu X, Nakazawa T, Aoki S, Nakamura T, Guilderson T, LaFranchi B, Mukai H, Terao Y, Uchida M, Kondo M. 2013. Initial results of an intercomparison of AMSbased atmospheric ${ }^{14} \mathrm{CO}_{2}$ measurements. Radiocarbon, these proceedings, doi:10.2458/ azu_js_rc.55.16382.

Newman S, Jeong S, Fischer ML, Xu X, Haman CL, Lefer B, Alvarez S, Rappenglueck B, Kort EA, Andrews A, Peischl J, Gurney KR, Miller CE, Yung YL. 2012. Diurnal tracking of anthropogenic $\mathrm{CO}_{2}$ emis- sions in the Los Angeles basin megacity during spring 2010. Atmospheric Chemistry and Physics Discussions 12:5771-801.

Polach H. 1989. ${ }^{14}$ CARE. Radiocarbon 31(3):422-30.

Scott EM. 2003. The Third International Radiocarbon Intercomparison (TIRI) and the Fourth International Radiocarbon Intercomparison (FIRI), 1990-2002. Results, Analyses, and Conclusions. Radiocarbon 45(2): 135-408.

Stuiver M, Polach HA. 1977. Discussion: reporting of ${ }^{14} \mathrm{C}$ data. Radiocarbon 19(3):355-63.

Thoning KW, Kitzis DR, Crotwell A. 2012. Atmospheric Carbon Dioxide Dry Air Mole Fractions from quasicontinuous measurements at Barrow, Alaska; Mauna Loa, Hawaii; American Samoa; and South Pole, 1973-2011. Version: 2012-05-07. Path: ftp:// ftp.cmdl.noaa.gov/ccg/co2/in-situ/.

Tyler SC, Rice A, Ajie HL. 2007. Stable isotope ratios in atmospheric $\mathrm{CH}_{4}$ : implications for seasonal sources and sinks. Journal of Geophysical Research 112: D03303, doi:10.1029/2006JD007231.

World Meteorological Organization [WMO]. 2011. Expert group recommendations. In: Brand W, editor. Report of the 15th WMO/IAEA Meeting of $\mathrm{CO}_{2}$ Experts on Carbon Dioxide, Other Greenhouse Gases and Related Tracers Measurements Techniques, Jena, Germany, 7-10 September 2009. WMO TD No. 1553. Geneva: World Meteorological Organization Atmospheric Watch. p 1-37.

$\mathrm{Xu}$ X, Trumbore SE, Ajie H, Tyler S. 2007a. ${ }^{14} \mathrm{C}$ of atmospheric $\mathrm{CO}_{2}$ over the subtropical and equatorial $\mathrm{Pa}$ cific from fall 2002 to summer 2005 and at Point Barrow, Alaska, USA from 2002 to 2007. Eos Transactions $A G U$ 88(52), Fall Meeting Supplement, Abstract B43D-1581.

Xu X, Trumbore SE, Zheng S, Southon JR, McDuffee KE, Luttgen M, Liu JC. 2007b. Modifying a sealed tube zinc reduction method for preparation of AMS graphite targets: reducing background and attaining high precision. Nuclear Instruments and Methods in Physics Research B 259(1):320-9. 